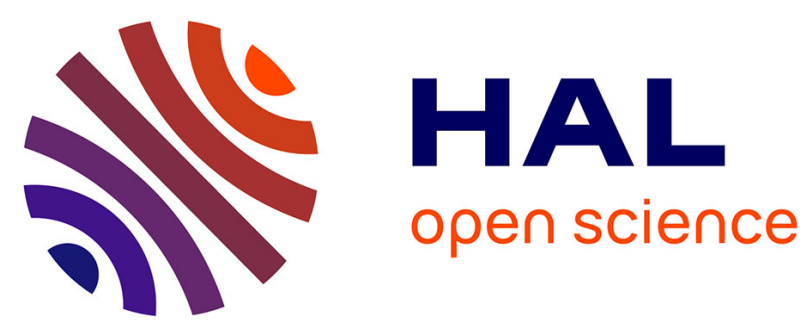

\title{
Complications after surgery for mesial temporal lobe epilepsy associated with hippocampal sclerosis
}

Bertrand Mathon, Vincent Navarro, Franck Bielle, Vi-Huong Nguyen-Michel, Alexandre Carpentier, Michel Baulac, Philippe Cornu, Claude Adam, Sophie Dupont, Stéphane Clemenceau

\section{To cite this version:}

Bertrand Mathon, Vincent Navarro, Franck Bielle, Vi-Huong Nguyen-Michel, Alexandre Carpentier, et al.. Complications after surgery for mesial temporal lobe epilepsy associated with hippocampal sclerosis. World Neurosurgery, 2017, 10.1016/j.wneu.2017.03.128 . hal-01504836

\section{HAL Id: hal-01504836 \\ https://hal.sorbonne-universite.fr/hal-01504836}

Submitted on 10 Apr 2017

HAL is a multi-disciplinary open access archive for the deposit and dissemination of scientific research documents, whether they are published or not. The documents may come from teaching and research institutions in France or abroad, or from public or private research centers.
L'archive ouverte pluridisciplinaire HAL, est destinée au dépôt et à la diffusion de documents scientifiques de niveau recherche, publiés ou non, émanant des établissements d'enseignement et de recherche français ou étrangers, des laboratoires publics ou privés. 
Complications after surgery for mesial temporal lobe epilepsy associated with hippocampal sclerosis

Bertrand MATHON, MD ${ }^{1,6}$, Vincent NAVARRO, MD,PhD ${ }^{2,5,6}$, Franck BIELLE, $M^{3,6}$, Vi-Huong NGUYEN-MICHEL, MD ${ }^{2}$, Alexandre CARPENTIER, MD,PhD ${ }^{1,5,6}$, Michel BAULAC, MD $^{2,5,6}$, Philippe CORNU, MD ${ }^{1,6}$, Claude ADAM, MD ${ }^{2,5}$, Sophie DUPONT, MD,PhD ${ }^{2,4,5,6}$, Stéphane CLEMENCEAU, MD $^{1}$.

1 AP-HP, Department of Neurosurgery, La Pitié-Salpêtrière University Hospital, Paris, France

2 AP-HP, Epilepsy Unit, La Pitié-Salpêtrière University Hospital, Paris, France

3 AP-HP, Department of Neuropathology, La Pitié-Salpêtrière University Hospital, Paris, France

4 AP-HP, Department of Rehabilitation, La Pitié-Salpêtrière University Hospital, Paris, France

5 Brain and Spine Institute (CRICM - ICM; INSERM, UMRS 1127; CNRS, UMR 7225), Paris, France

6 Sorbonne University, UPMC, Univ Paris 06, Paris, France

\section{Corresponding author:}

Dr Bertrand MATHON

Department of Neurosurgery, Groupe Hospitalier Universitaire de La Pitié-Salpêtrière 47-83, Boulevard de l'Hôpital 75013 Paris, France.

Email: bertrand.mathon@aphp.fr 
Manuscript: 2963 words

Abstract: 248 words

Figures: 1 / Tables: 7 / Supplementary File, online only: 1

References: 39

\section{Key Words:}

Adverse events; Epilepsy surgery; Mesial temporal sclerosis; Morbidity; Predictors;

Visual field defects 


\section{ABSTRACT}

Background. Hippocampal sclerosis is the most common cause of drug-resistant epilepsy amenable for surgical treatment and seizure control. This study aimed to analyze morbidities related to surgery of mesial temporal lobe epilepsy associated with hippocampal sclerosis and to identify possible risk factors for complications. Methods. A retrospective analysis of postoperative complications was made for 389 operations performed between 1990 and 2015 on patients aged 15 to 67 years (mean 36.8). Three surgical approaches were used: anterior temporal lobectomy (ATL) $(n=209)$, transcortical selective amygdalohippocampectomy $(\mathrm{SAH})(\mathrm{n}=144)$ and transylvian SAH $(n=36)$. Complications were classified as minor, or major if there was a neurological impairment or if further surgical or medical treatment was needed. Results. Complications followed $15.4 \%$ of operations. They were classed as major for $4.1 \%$ of patients, but there were no mortalities. Persistent neurological deficits occurred in $0.5 \%$ of patients. In 3 cases $(0.8 \%)$ additional surgery was needed to treat an intracranial hematoma, a delayed hydrocephalus and a subdural empyema. Symptomatic visual field defects (VFDs) were frequent and included contralateral superior quadrantanopia (8.2\%) or hemianopia (1.3\%). Overall complications $(P=0.04)$ and symptomatic VFDs $(P=0.04)$ were most frequent in operations on men. Major complications occurred most often with the ATL surgical approach than with transcortical SAH $(P=0.03)$.

Conclusions. Major complications occur rarely after mesial temporal surgery on epileptic patients. They occur more often following ATL than transcortical SAH approach. Complications tend to be temporary with symptoms of limited duration for surgery performed by experienced teams on carefully selected and evaluated patients. 


\section{INTRODUCTION}

Mesial temporal lobe epilepsy (MTLE) associated with hippocampal sclerosis (HS) is the most common focal, intractable epilepsy. ${ }^{1}$ Mesial temporal lobe surgery, the standard treatment for this syndrome, has been widely evaluated. ${ }^{2}$ Diverse surgical approaches ensure a reduced seizure frequency. They include a selective transylvian or transcortical amygdalohippocampectomy (SAH) and an anterior temporal lobectomy (ATL). ${ }^{1,2}$

While these surgical approaches are safe, possible morbidities and even mortality must be discussed with patients before surgery. Few studies have focused on adverse events after MTLE surgery. ${ }^{3}$ Accurate data on outcomes and complications would aid presurgical discussions with patients and also permit a useful comparative evaluation of different surgical approaches. We therefore conducted a 25 -year retrospective study on the morbidity and mortality of MTLE-HS surgery in all patients operated in our institution. Mesial temporal lobe surgery has evolved over the duration of this retrospective study so that we could compare different surgical approaches for mesial temporal lobe resection. Each approach had its own advantages and consequences.

The primary aim of this report is therefore to describe, analyze and discuss the complications related to MTLE-HS surgery. A secondary endpoint was to search for factors that might increase the possibility of post-operative complications.

\section{$\underline{\text { METHODS }}$}

\section{Patients}

We analyzed retrospectively the after-effects of surgery for MTLE-HS in all adult and teenagers (over 15 years) patients treated in our institution between November 1990 and December 2015, and who were followed for at least 6 months. This study was approved by the French National Technologies and Civil Liberties Commission, which ensures the protection of personal data. 
Patients were selected for surgery after medical management of seizures had failed. Standardized, non-invasive presurgical evaluation included: complete neurological, neuropsychological and psychiatric examinations, scalp video-EEG recording of seizures, brain MRI, and when needed subtraction ictal single photon emission computed tomography co-aligned with MRI and interictal positron emission tomography. A multidisciplinary team then analyzed data from these investigations to decide if surgical treatment was indicated and if localization of the focus was clear. If so, strict selection criteria were used to define a single-stage surgical resection, avoiding further intracranial EEG recordings whenever possible. Selection criteria for surgery included the presence of typical partial seizures, epileptiform activity originating from the temporal lobe and unilateral hippocampal atrophy with or without a T2 hyperintense signal, all features of a classical MTLE-HS syndrome.

We collected data on age, gender, medical history, seizure semiology, electrophysiological findings including invasive recordings if applicable, preoperative brain MRI images, side and approach of surgery and histological findings. Any adverse event during the postoperative period was considered as a complication and documented from neurological examinations, postoperative scans and formal visual field testing.

\section{Surgical methodology}

Three surgical approaches were used: (1) Spencer's ATL; ${ }^{4}$ or (2) SAH via transylvian approach; ${ }^{5}$ and (3) SAH via transcortical trans-STG approach. ${ }^{6}$ ATL was used between 1990 and 2010, and transylvian SAH between 1994 and 2000. SAH with a transcortical approach was first used in 2000. The senior author (S.C.) performed all surgeries. The decision to perform an ATL or an SAH was first based on timing, and then on the results of the presurgical evaluation. Before 1994, patients who underwent surgery for MTLE-HS received an ATL, as this was the practice at our center. Between 1994 and 2010, SAH was used for patients with a high risk of postoperative cognitive deterioration. In 2010, the transcortical SAH was definitively adopted as the standard operation for MTLE-HS. 


\section{Postoperative management}

Patients were monitored in the recovery unit after surgery. A CT scan was done within 24 hours to exclude immediate complications, before transfer to the Neurosurgery unit. All patients were followed at regular intervals after surgery. At 69 months after surgery, complete neurological and ophthalmological assessments were made and a follow-up brain MRI was obtained.

\section{Classification of complications}

Two severity scales for postoperative complications after MTLE surgery were designed to permit comparison with previous studies: (1) a binary major/minor scale: a complication was defined as major if medical or surgical treatment was needed and/or if there was a persistent neurologic impairment. Other complications, including UTI and DVT, were classed as minor. (2) A graded scale, as follows, with composite items including a prevailing surgical component: ${ }^{7,8}$

- Grade 0: no complication.

- Grade 1: a transient complication not needing treatment; or non-invalidating homonymous contralateral superior quadrantanopia.

- Grade 2: a transient complication that resolved completely but required surgical or medical treatment.

- Grade 3: a persistent neurological or visual deficit that affected daily activities for more than 6 months

- Grade 4: death linked to the surgery.

Other adverse events after surgery, such as meningeal syndrome, low-grade fever, headaches, pneumocephalus, were considered as mild functional disturbances rather than complications. 


\section{Statistical analysis}

Statistical analysis was performed with version 21 of SPSS (IBM; Armonk, NY, USA). Simultaneous binary logistic regression models were used to evaluate the ability of independent variables to predict complications. Exploratory univariate analysis was performed using the t-test of Student for quantitative variables (age at surgery, epilepsy duration) and the chi-square or Fisher exact test for dichotomous variables (gender, preoperative data, surgical approach, side of surgery and HS histological type). Independent variables correlating with complication variables at the $20 \%$ level or less $(P<0.2)$ were considered for entry into the model. Independent variables without significant predictive value at the $5 \%$ level $(P \leq 0.05)$ were then eliminated, and final analysis carried out.

\section{$\underline{\text { RESULTS }}$}

\section{Patient demographics, surgery and seizure outcome}

This analysis is based on 389 patients with severe and/or disabling drugresistant epilepsy who underwent mesial temporal lobe resection for MTLE-HS. Their age at surgery was $36.8 \pm 10.5$ years (range, 15.4-67.9); the male/female ratio was 0.90. The first seizure for these patients occurred at 12.0 \pm 9.1 years (range, 0.0-47.4) and the mean seizure frequency was $6 \pm 5$ seizures per month (range $0.5-100$ ). Surgical approaches for these patients were ATL in 209 cases (53.7\%), trans-STG SAH for 144 patients (37.0\%) and transylvian SAH for 36 cases (9.3\%). 206 patients $(53.0 \%)$ were operated on the left hemisphere, and 183 (47.0\%) on the right.

Histological examination performed according to ILAE classification ${ }^{9}$ found a type 1 HS for 189 patients (75.3\%), a type 2 HS for 47 patients (18.7\%), a type 3 HS for 3 patients (1.2\%) and no sclerosis was detected for 12 patients (type no-HS, 4.8\%).

Seizure outcome was defined as follow up at a time point $>1$ year after surgery in 361 patients. The mean duration of follow-up for the cohort was $8.7 \pm 5.8$ years (range, 1.0 to 25.2 years). Three hundred two patients $(83.7 \%)$ were free from 
seizures (Engel class I) at the latest follow-up evaluation after surgery $(8.7 \pm 5.8$ years) and 206 patients $(57.1 \%)$ had a class Ia outcome. ${ }^{10}$

\section{Overall complications}

For 329 patients $(84.6 \%)$ recovery from surgery was uneventful. Table 1 and Fig. 1A summarize complications of the other 60 patients (15.4\%). For 44 patients $(11.3 \%)$ they were minor. Major complications followed 16 operations $(4.1 \%)$ and led to a prolonged hospitalization for 9 patients (2.3\%; Fig. 1B). On the graded scale described in the Methods, 44 patients $(11.3 \%)$ had a grade 1 complication, $8(2.1 \%)$ a grade 2 complication and a more severe grade 3 complication occurred for 8 patients (2.1\%; Table 1 and Fig. 1C). There were no deaths after surgery. A further surgical intervention was needed for 3 of the 60 patients with complications $(0.8 \%)$.

Only one parameter was significantly associated with complications. They occurred more often in male than in female patients (18.5\% versus $12.7 \%, P=0.04$; $\left.\mathrm{OR}=2.1 ; \mathrm{IC}_{95 \%}=[1.0-4.1]\right)$. Table 2 compares groups with and without complications. In terms of the surgical approach, Table 3 shows that ATL was more often associated with major complications than transcortical SAH (5.7\% versus $2.1 \%$ respectively, $\left.P=0.03 ; \mathrm{OR}=4.4 ; \mathrm{IC}_{95 \%}=[1.1-17.2]\right)$.

\section{Surgical complications}

Complications for 7 patients $(1.8 \%)$ were classed as surgical. They were meningitis in 4 cases $(1.0 \%)$ and 1 case each of subdural empyema, intracranial hemorrhage and delayed hydrocephalus (Table 1 and Fig. 1A). Antibiotic treatment was effective for all patients with meningitis. Surgical intervention was needed in the other 3 cases $(0.8 \%)$, all after ATL.

One of these cases was a 52-year old woman, where a CT scan on the 7th day after the operation in response to hyperthermia and subcutaneous abscesses near the wound, revealed a subdural temporal empyema (pathogenic agent Aureus staphylococcus), which required surgical drainage and antibiotic therapy. At 2 years after the operation in a 21-year old woman, we detected a hydrocephalus by cystic 
compartmentalization of the ventricular temporal horn, requiring a ventriculoperitoneal shunt. Lastly, a 57-year old man developed an acute intracerebral hemorrhage with mass effect at the surgical site. Surgical intervention was followed by intensive care. All these patients recovered totally from surgical complications, which were classed as grade 2. A similar comparison for surgical complications as in Table 3 was made but there were no differences between patients with and without surgical complications (Supplementary Table 1).

\section{Neurological complications}

For 15 patients (3.9\%) complications were neurological (Table 1 and Fig. 1A). Deficits were transient in 11 cases $(2.8 \%)$, but damage was persistent for 1 patient with hemiplegia and 1 with hemiparesis $(0.5 \%)$. Two patients $(0.6 \%)$ had a cerebral venous sinus thrombosis diagnosed from severe headaches and managed by anticoagulation. Patients who suffered a transient aphasia or hemiparesis typically recovered fully within days (grade 1 complication). A 40-year old man experienced a postoperative oculomotor nerve paralysis, which resolved completely by the followup evaluation at 9 months (grade 3 complication). The two persistent neurological impairments occurred after ATL.

While neurological complications occurred more frequently after ATL (5.3\%) than after transcortical SAH $(1.4 \%)$, the difference was not statistically significant $(P$ $=0.08$ ). No significant differences were evident in groups with or without neurological complications (Table 4).

\section{Visual field defects}

Postoperative Goldmann visual field testing of 323 patients revealed deficits in 125 cases (38.7\%; Fig. 1D). Only $9.5 \%$ of the 389 patients had a symptomatic deficit; a homonymous superior contralateral quadrantanopia in 32 cases $(8.2 \%)$ and a homonymous contralateral hemianopia in 5 cases (1.3\%) (Table 1 and Fig. 1A, D). Quadrantic VFD after the operation never affected daily life. Symptomatic VFD 
occurred more frequently in male than female patients $\left(P=0.04 ; \mathrm{OR}=2.2 ; \mathrm{IC}_{95 \%}=\right.$ [1.0-4.6], Table 5).

\section{DISCUSSION}

\section{Overall complications}

This study on adverse events after operations for MTLE-HS conducted over 25 years in a tertiary French center, revealed an overall rate of complications of 15.4 $\%$. This value is close to previous reports for adults, of 5.5\%-19.0\% (Table 6). ${ }^{3,11-20}$ Major complications, which require further medical or surgical treatment or result in a persistent deficit, occur rarely after this operation. ${ }^{1,2}$ We found a rate of $4.1 \%$, compared to previous reports of $1.8 \%$ to $13.4 \%$ (Table 6). ${ }^{3,12-18,21}$ There are significant differences in how different studies have classified major complications. Here we analyzed each complication using two severity scales to allow objective comparison with previous work. Retrospective studies might misjudge incidence of UTIs, DVT and VFDs. We recommend that new studies of complications after epilepsy surgery standardize severity of outcome and tests of visual deficit.

Persistent neurological deficits occurred in very few, $0.5 \%$, operations. Reported frequencies vary from 0 to $3.1 \%$ (Table 6). ${ }^{3,12-15,17,18,20}$ Hemiparesis, the most common serious neurological impairment, is typically triggered by an injury to the anterior choroidal artery ${ }^{22}$ or by cerebral swelling. Another risks during resection of mesial structures are to damage the motor pathways or provoke a cerebral vasospasm, resulting in stroke. ${ }^{23}$ Mortality after MTLE-HS surgery is very rare $(<$ $0.5 \%)^{24}$ and was null in our series.

Changes in MTLE-HS surgery represent an evolution of neurosurgical techniques. The large cohort studied here let us compare different surgical approaches used over 25 years on a homogenous group of patients with MTLE-HS. Worldwide, there has been a strong trend to reduce the extent of resections. ${ }^{25}$ The SAH approach aims to spare cerebral tissue that does not contribute to seizure generation, although the volume of temporal lobe that should be resected is still debated. ${ }^{2}$ In our series, 
ATL was associated with major complications more often than transcortical SAH (5.7\% versus $2.1 \%)$. Neurological complications also occurred more frequently after ATL $(5.3 \%)$ than after transcortical SAH (1.4\%), although this difference was not statistically significant $(P=0.08)$. Possibly the larger surgical cavity made during ATL enhances bleeding, infection, and even hydrocephalus. ${ }^{26}$ We note that comparisons of transylvian SAH with the other two surgical approaches possess less weight since surgery with this procedure was done in only 36 patients. The literature suggests a higher risk of cerebral vasospasm with transylvian SAH perhaps because this approach necessitates manipulation of the middle cerebral artery branches in the Sylvian fissure. Different mechanisms have been proposed to explain the pathophysiology of cerebral vasospasm. ${ }^{23}$ None of the patients in this study experienced symptomatic cerebral vasospasm. Different surgical centers suggest that one advantage of transcortical SAH is to minimize the need to divide vascular adhesions which is tedious, time consuming, and which sometimes provokes a degree of cerebral swelling. ${ }^{25}$ A multicenter randomized trial might usefully compare the safety profile of different approaches in MTLE surgery.

This study found significantly more postoperative complications for male than for female patients. Otherwise we did not identify preoperative clinical, radiological and electrophysiological data that could predict postsurgical complications. Neither the cerebral hemisphere involved (left or right) nor the histopathology of the sclerosis provided indications on adverse post-operative events. Some authors suggest that age at surgery may be linked to complications, ${ }^{3,11}$ but our data did not support such a link, even if the age range of patients in this work was relatively small. Attention to these factors together with a detailed knowledge of mesial temporal lobe microsurgical anatomy may help reduce postsurgical complications. ${ }^{6}$

\section{Visual field defects}

Visual field deficits often occur after MTLE surgery. Typically they consist of a contralateral superior quadrantanopia due to injury of Meyer's Loop during access to mesial temporal structures. Standard Goldmann perimetry revealed VFDs in $38.7 \%$ of this cohort of which only $9.5 \%$ were symptomatic. These deficits rarely affect daily life after surgery. The literature reports very heterogeneous rates of VFD, between 
$15 \%$ and $100 \%$ (Table 7), ${ }^{27-35}$ with severe deficits after $2 \%-35 \%$ of operations. ${ }^{11,33,35}$ However, visual fields were not formally tested in several of these studies, and the delay between the operation and post-surgical follow-up was variable. This delay influences visual deficit. In the study of Yam et al., ${ }^{35} 38 \%$ of the patients with severe VFD just after their operation report improvement with time.

Male patients were significantly more likely to report VFD symptoms. This could be related to earlier return to work in males or participating in driving or other visual coordination tasks compared to female patients. We found no difference in post-operative symptomatic VFD frequency after surgery involving SAH or ATL. In contrast, Mengesha et al. ${ }^{33}$ report VFDs were more evident after ATL than transcortical SAH, where the visual field close to the horizontal meridian was relatively spared.

Surgical approaches to minimize subsequent visual deficits can be envisioned. To protect fibers of Meyer's loop, we recommend to open the ventricle anteriorly through the floor and not to resect tissue posterosuperior to the temporal horn. Excessive posterolateral opening of the ventricle wall should also be avoided to protect optic radiations. ${ }^{6}$ Preoperative tractographic data on Meyer's loop, especially for left-side temporal lobe epilepsies, can also help reduce to optic radiation injury. ${ }^{36}$

\section{Comparison to other surgical techniques for MTLE-HS treatment}

MTLE-HS surgery has also been made using stereotaxic radiosurgery. The most frequent adverse event after stereotaxic radiosurgery is headache (70\%). Further $50-62.5 \%$ of patients experience a contralateral superior quadrantanopia, fairly similar to the rate described after open surgery. ${ }^{37,38}$ Adverse events occurring more rarely include brain edema, intracranial hypertension and transient increase of seizure frequency. There are reports of tumor genesis and progressive cognitive disorders. ${ }^{39}$

Amygdalohippocampal stimulation shows some therapeutic promise for MTLE. Studies on the safety of the procedure suffer from small sample sizes and short follow-up times. However, surgical practices used to implant deep brain electrodes for movement disorders are relevant. The risk of hemorrhage is about $5 \%$. 
This includes intracerebral hemorrhage along the course of the stimulating electrode, and potential postoperative subdural or epidural hematoma. ${ }^{21}$ Infections also occur with a risk of at least $5 \%$ and require removal of stimulating electrode. ${ }^{40}$

\section{Limitations of the study}

This study was based on a large, homogeneous, representative cohort of patients with MTLE-HS and allowed the direct comparison between three surgical approaches. However, it was a retrospective study that concerned just one center. Patients were not randomized to the distinct surgical approaches. Cognitive complications, which certainly affect the quality of life after surgery, were not considered. Our findings might usefully be re-examined in further large-scale, randomized studies.

\section{CONCLUSIONS}

This retrospective study revealed a low rate of complications after surgical resections for MTLE-HS. The rate of mortality was zero, $0.5 \%$ of patients ( 2 of 389 ) suffered persistent neurological deficits, and, mainly with ATL, major events occurred after only $4.1 \%$ of operations. The risk of complications has decreased with improved surgical techniques, anesthesia, and postoperative management. The low complication rate contributes to an acceptable surgical treatment, which can be accurately described in discussions of benefits and risks with patients who are considering treatment options for a pharmacoresistant MTLE epileptic syndrome.

Debate persists on the optimal extent and surgical procedure for temporal lobe resections. Our data suggest that transcortical SAH is the preferred approach to minimize complications of MTLE-HS surgery. This conclusion should be confirmed in a randomized comparison of SAH and ATL. Further reductions in post-operative complications will result from an improved understanding of temporal lobe anatomy and especially from technical enhancements in MTLE-HS surgical procedures. 


\section{ACKNOWLEDGMENTS}

The authors thank Dr. Richard Miles for advice and discussion concerning the manuscript.

\section{FUNDING}

This work received support from the program 'Investissements d'avenir' ANR-10IAIHU-06.

\section{CONFLICTS OF INTEREST}

None of the authors has any conflict of interest to disclose.

\section{REFERENCES}

1. Mathon B, Bedos-Ulvin L, Baulac M, Dupont S, Navarro V, Carpentier A, Cornu P, Clemenceau S. [Evolution of ideas and techniques, and future prospects in epilepsy surgery]. Rev Neurol (Paris). Feb 2015;171(2):141-156.

2. Mathon B, Bedos Ulvin L, Adam C, Baulac M, Dupont S, Navarro V, Cornu $\mathrm{P}$, Clemenceau S. Surgical treatment for mesial temporal lobe epilepsy associated with hippocampal sclerosis. Rev Neurol (Paris). Mar 2015; 171(3):315-325.

3. Vale FL, Reintjes S, Garcia HG. Complications after mesial temporal lobe surgery via inferiortemporal gyrus approach. Neurosurg Focus. Jun 2013;34(6):E2.

4. Spencer DD, Spencer SS, Mattson RH, Williamson PD, Novelly RA. Access to the posterior medial temporal lobe structures in the surgical treatment of temporal lobe epilepsy. Neurosurgery. Nov 1984;15(5):667-671. 
5. Wieser HG, Yasargil MG. Selective amygdalohippocampectomy as a surgical treatment of mesiobasal limbic epilepsy. Surg Neurol. Jun 1982;17(6):445457.

6. Mathon B, Clemenceau S. Selective amygdalohippocampectomy via transsuperior temporal gyrus keyhole approach. Acta Neurochir(Wien). Apr 2016;158(4):785-789.

7. Mathon B, Clemenceau S, Hasboun D, Habert MO, Belaid H, Nguyen-Michel VH, Lambrecq V, Navarro V, Dupont S, Baulac M, Cornu P, Adam C. Safety profile of intracranial electrode implantation for video-EEG recordings in drug-resistant focal epilepsy. J Neurol. Dec 2015;262(12):2699-2712.

8. Wellmer J, von der Groeben F, Klarmann U, Weber C, Elger CE, Urbach H, Clusmann H, von Lehe M. Risks and benefits of invasive epilepsy surgery workup with implanted subdural and depth electrodes. Epilepsia. Aug 2012;53(8):1322-1332.

9. Blumcke I, Thom M, Aronica E, Armstrong DD, Bartolomei F, Bernasconi A, Bernasconi N, Bien CG, Cendes F, Coras R, Cross JH, Jacques TS, Kahane P, Mathern GW, Miyata H, Moshe SL, Oz B, Ozkara C, Perucca E, Sisodiya S, Wiebe S, Spreafico R. International consensus classification of hippocampal sclerosis in temporal lobe epilepsy: a Task Force report from the ILAE Commission on Diagnostic Methods. Epilepsia. Jul 2013;54(7):1315-1329.

10. Mathon B, Navarro V, Carpentier A, Bielle F, Cornu P, Clemenceau S. Résultats et facteurs pronostiques de la chirurgie de l'épilepsie mésiotemporale associée à une sclérose hippocampique. Congrès de la Société de Neurochirurgie de Langue Française Vol 63. Paris: Neurochirurgie; 2016:3152.

11. Rydenhag B, Silander HC. Complications of epilepsy surgery after 654 procedures in Sweden, September 1990-1995: a multicenter study based on the Swedish National Epilepsy Surgery Register. Neurosurgery. Jul 2001;49(1):51-56; discussion 56-57.

12. Behrens E, Schramm J, Zentner J, Konig R. Surgical and neurological complications in a series of 708 epilepsy surgery procedures. Neurosurgery. Jul 1997;41(1):1-9; discussion 9-10. 
13. Salanova V, Markand O, Worth R. Temporal lobe epilepsy surgery: outcome, complications, and late mortality rate in 215 patients. Epilepsia. Feb 2002;43(2):170-174.

14. Sindou M, Guenot M, Isnard J, Ryvlin P, Fischer C, Mauguiere F. Temporomesial epilepsy surgery: outcome and complications in 100 consecutive adult patients. Acta Neurochir (Wien). Jan 2006;148(1):39-45.

15. Bate H, Eldridge $\mathrm{P}$, Varma T, Wieshmann UC. The seizure outcome after amygdalohippocampectomy and temporal lobectomy. Eur J Neurol. Jan 2007;14(1):90-94.

16. Tanriverdi T, Ajlan A, Poulin N, Olivier A. Morbidity in epilepsy surgery: an experience based on 2449 epilepsy surgery procedures from a single institution. J Neurosurg. Jun 2009;110(6):1111-1123.

17. Bandt SK, Werner N, Dines J, Rashid S, Eisenman LN, Hogan RE, Leuthardt EC, Dowling J. Trans-middle temporal gyrus selective amygdalohippocampectomy for medically intractable mesial temporal lobe epilepsy in adults: seizure response rates, complications, and neuropsychological outcomes. Epilepsy Behav. Jul 2013;28(1):17-21.

18. Iachinski RE, de Meneses MS, Simao CA, da Rocha SF, de Oliveira Braga F, Kowacs PA. Patient satisfaction with temporal lobectomy/selective amygdalohippocampectomy for temporal lobe epilepsy and its relationship with Engel classification and the side of lobectomy. Epilepsy Behav. Feb 2014;31:377-380.

19. Yang PF, Zhang HJ, Pei JS, Lin Q, Mei Z, Chen ZQ, Jia YZ, Zhong ZH, Zheng ZY. Keyhole epilepsy surgery: corticoamygdalohippocampectomy for mesial temporal sclerosis. Neurosurg Rev. Jan 2016;39(1):99-108; discussion 108.

20. Josephson CB, Dykeman J, Fiest KM, Liu X, Sadler RM, Jette N, Wiebe S. Systematic review and meta-analysis of standard vs selective temporal lobe epilepsy surgery. Neurology. Apr 30 2013;80(18):1669-1676.

21. Boviatsis EJ, Stavrinou LC, Themistocleous M, Kouyialis AT, Sakas DE. Surgical and hardware complications of deep brain stimulation. A seven-year experience and review of the literature. Acta Neurochir (Wien). Dec 2010;152(12):2053-2062. 
22. Helgason C, Caplan LR, Goodwin J, Hedges T, 3rd. Anterior choroidal arteryterritory infarction. Report of cases and review. Arch Neurol. Jul 1986;43(7):681-686.

23. Lackner P, Koppelstaetter F, Ploner P, Sojer M, Dobesberger J, Walser G, Schmutzhard E, Schmidauer C, Bauer R, Unterberger I, Ortler M, Trinka E. Cerebral vasospasm following temporal lobe epilepsy surgery. Neurology. Apr 17 2012;78(16):1215-1220.

24. Wiebe S, Blume WT, Girvin JP, Eliasziw M, Effectiveness, Efficiency of Surgery for Temporal Lobe Epilepsy Study G. A randomized, controlled trial of surgery for temporal-lobe epilepsy. N Engl J Med. Aug 2 2001;345(5):311318.

25. Tanriverdi T, Olivier A, Poulin N, Andermann F, Dubeau F. Long-term seizure outcome after mesial temporal lobe epilepsy surgery: corticalamygdalohippocampectomy versus selective amygdalohippocampectomy. J Neurosurg. Mar 2008;108(3):517-524.

26. Chabardes S, Minotti L, Hamelin S, Hoffmann D, Seigneuret E, Carron R, Krainik A, Grand S, Kahane P, Benabid AL. [Temporal disconnection as an alternative treatment for intractable temporal lobe epilepsy: techniques, complications and results]. Neurochirurgie. May 2008;54(3):297-302.

27. Egan RA, Shults WT, So N, Burchiel K, Kellogg JX, Salinsky M. Visual field deficits in conventional anterior temporal lobectomy versus amygdalohippocampectomy. Neurology. Dec 26 2000;55(12):1818-1822.

28. Hervas-Navidad R, Altuzarra-Corral A, Lucena-Martin JA, CastanedaGuerrero M, Vela-Yebra R, Sanchez AlJC. [Defects in the visual field in resective surgery for temporal lobe epilepsy]. Rev Neurol. Jun 1-15 2002;34(11):1025-1030.

29. Pathak-Ray V, Ray A, Walters R, Hatfield R. Detection of visual field defects in patients after anterior temporal lobectomy for mesial temporal sclerosisestablishing eligibility to drive. Eye (Lond). Nov 2002;16(6):744-748.

30. Nilsson D, Malmgren K, Rydenhag B, Frisen L. Visual field defects after temporal lobectomy -- comparing methods and analysing resection size. Acta Neurol Scand. Nov 2004;110(5):301-307. 
31. Barton JJ, Hefter R, Chang B, Schomer D, Drislane F. The field defects of anterior temporal lobectomy: a quantitative reassessment of Meyer's loop. Brain. Sep 2005;128(Pt 9):2123-2133.

32. Yeni SN, Tanriover N, Uyanik O, Ulu MO, Ozkara C, Karaagac N, Ozyurt E, Uzan M. Visual field defects in selective amygdalohippocampectomy for hippocampal sclerosis: the fate of Meyer's loop during the transsylvian approach to the temporal horn. Neurosurgery. Sep 2008;63(3):507-513; discussion 513-505.

33. Mengesha T, Abu-Ata M, Haas KF, Lavin PJ, Sun DA, Konrad PE, Pearson M, Wang L, Song Y, Abou-Khalil BW. Visual field defects after selective amygdalohippocampectomy and standard temporal lobectomy. $J$ Neuroophthalmol. Sep 2009;29(3):208-213.

34. Jeelani NU, Jindahra P, Tamber MS, Poon TL, Kabasele P, James-Galton M, Stevens J, Duncan J, McEvoy AW, Harkness W, Plant GT. 'Hemispherical asymmetry in the Meyer's Loop': a prospective study of visual-field deficits in 105 cases undergoing anterior temporal lobe resection for epilepsy. $J$ Neurol Neurosurg Psychiatry. Sep 2010;81(9):985-991.

35. Yam D, Nicolle D, Steven DA, Lee D, Hess T, Burneo JG. Visual field deficits following anterior temporal lobectomy: long-term follow-up and prognostic implications. Epilepsia. Jun 2010;51(6):1018-1023.

36. Dreessen de Gervai P, Sboto-Frankenstein UN, Bolster RB, Thind S, Gruwel ML, Smith SD, Tomanek B. Tractography of Meyer's Loop asymmetries. Epilepsy Res. Jul 2014;108(5):872-882.

37. Regis J, Rey M, Bartolomei F, Vladyka V, Liscak R, Schrottner O, Pendl G. Gamma knife surgery in mesial temporal lobe epilepsy: a prospective multicenter study. Epilepsia. May 2004;45(5):504-515.

38. Barbaro NM, Quigg M, Broshek DK, Ward MM, Lamborn KR, Laxer KD, Larson DA, Dillon W, Verhey L, Garcia P, Steiner L, Heck C, Kondziolka D, Beach R, Olivero W, Witt TC, Salanova V, Goodman R. A multicenter, prospective pilot study of gamma knife radiosurgery for mesial temporal lobe epilepsy: seizure response, adverse events, and verbal memory. Ann Neurol. Feb 2009;65(2):167-175. 
39. McIver JI, Pollock BE. Radiation-induced tumor after stereotactic radiosurgery and whole brain radiotherapy: case report and literature review. $J$ Neurooncol. Feb 2004;66(3):301-305.

40. Bjerknes S, Skogseid IM, Saehle T, Dietrichs E, Toft M. Surgical site infections after deep brain stimulation surgery: frequency, characteristics and management in a 10-year period. PLoS One. 2014;9(8):e105288. 


\section{FIGURE LEGEND}

Fig. 1 Quantification of different postoperative complications. A, Frequency of complications. B, Pie chart of the frequency of complication according to the class of complication. C, Pie chart of the frequency of complication according to the grade of complication. D, Pie chart of the frequency of visual field defects.

VFD, visual field defect. 


\begin{tabular}{|c|c|c|}
\hline Symptomatic complications & $\%(\mathrm{n} / \mathrm{N})$ & $\begin{array}{c}\text { Class - grade of } \\
\text { complications }\end{array}$ \\
\hline Transient hemiparesis & $1.3 \%(5 / 389)$ & Minor - Grade 1 \\
\hline Transient aphasia & $1.3 \%(5 / 389)$ & Minor - Grade 1 \\
\hline Definitive hemiparesis & $0.3 \%(1 / 389)$ & Major - Grade 3 \\
\hline Definitive hemiplegia & $0.3 \%(1 / 389)$ & Major - Grade 3 \\
\hline Cerebral venous sinus thrombosis & $0.5 \%(2 / 389)$ & Major - Grade 2/3 \\
\hline Transient oculomotor nerve paralysis & $0.3 \%(1 / 389)$ & Major - Grade 3 \\
\hline Neurological complications (total) & $3.9 \%(15 / 389)$ & \\
\hline Meningitis & $1.0 \%(4 / 389)$ & Major - Grade 2 \\
\hline Subdural empyema & $0.3 \%(1 / 389)$ & Major - Grade 2 \\
\hline Intracerebral hemorrhage & $0.3 \%(1 / 389)$ & Major - Grade 2 \\
\hline Hydrocephalus & $0.3 \%(1 / 389)$ & Major - Grade 2 \\
\hline Surgical complications (total) & $1.8 \%(7 / 389)$ & \\
\hline Homonymous quadrantanopia & $8.2 \%(32 / 389)$ & Minor - Grade 1 \\
\hline Homonymous hemianopia & $1.3 \%(5 / 389)$ & Major - Grade 3 \\
\hline Visual complications (total) & $9.5 \%(37 / 389)$ & \\
\hline Urinary tract infection & $1.0 \%(4 / 389)$ & Minor - Grade 1 \\
\hline Deep venous thrombosis & $0.5 \%(2 / 389)$ & Minor - Grade 1 \\
\hline Other complications (total) & $1.5 \%(6 / 389)$ & \\
\hline Overall complications & $15.4 \%(60 / 389)$ & \\
\hline
\end{tabular}

Table 1. Complications associated with mesial temporal lobe resection. 


\begin{tabular}{|c|c|c|c|c|}
\hline $\begin{array}{l}\text { Variables } \\
\text { n/N }(\%) \text { or mean } \pm \mathrm{SD}\end{array}$ & $\begin{array}{c}\text { No } \\
\text { complication }\end{array}$ & Complication & $\begin{array}{c}\text { Univariate } \\
P \text {-value }\end{array}$ & $\begin{array}{c}\text { Multivariate } \\
P \text {-value }\end{array}$ \\
\hline Age at surgery, $y$, mean \pm SD & $36.8 \pm 10.6$ & $37.1 \pm 9.9$ & 0.88 & \\
\hline Duration of epilepsy, $y$, mean \pm SD & $24.8 \pm 11.6$ & $25.8 \pm 10.5$ & 0.54 & \\
\hline Seizure frequency / $\mathrm{m}$, mean $\pm \mathrm{SD}$ & $11.1 \pm 14.4$ & $8.3 \pm 9.1$ & 0.17 & 0.24 \\
\hline Gender & $\begin{array}{l}150 / 184(81.5 \%) \\
179 / 205(87.3 \%)\end{array}$ & $\begin{array}{l}34 / 184(18.5 \%) \\
26 / 205(12.7 \%)\end{array}$ & 0.12 & $0.04 *$ \\
\hline $\begin{array}{c}\text { Dominant hand } \\
\text { Right } \\
\text { Left } \\
\text { Ambidextrous }\end{array}$ & $\begin{array}{c}281 / 331(84.9 \%) \\
39 / 46(84.8 \%) \\
6 / 9(66.7 \%)\end{array}$ & $\begin{array}{c}50 / 331(15.1 \%) \\
7 / 46(15.2 \%) \\
3 / 9(33.3 \%)\end{array}$ & 0.33 & \\
\hline $\begin{array}{r}\text { Associated disease } \\
\text { Yes } \\
\text { No }\end{array}$ & $\begin{array}{c}32 / 35(91.4 \%) \\
287 / 342(83.9 \%)\end{array}$ & $\begin{array}{c}3 / 35(8.6 \%) \\
55 / 342(16.1 \%)\end{array}$ & 0.33 & \\
\hline $\begin{array}{c}\text { Preoperative MRI } \\
\text { HS pattern } \\
\text { Normal }\end{array}$ & $\begin{array}{c}260 / 306(85.0 \%) \\
14 / 16(87.5 \%)\end{array}$ & $\begin{array}{c}46 / 306(15.0 \%) \\
2 / 16(12.5 \%)\end{array}$ & $>0.99$ & \\
\hline $\begin{array}{c}\text { EEG: bitemporal abnormalities } \\
\text { Yes } \\
\text { No }\end{array}$ & $\begin{array}{c}76 / 84(90.5 \%) \\
181 / 217(83.4 \%)\end{array}$ & $\begin{array}{c}8 / 84(9.5 \%) \\
36 / 217(16.6 \%)\end{array}$ & 0.15 & 0.24 \\
\hline $\begin{array}{c}\text { Extratemporal ictal abnormalities } \\
\text { Yes } \\
\text { No }\end{array}$ & $\begin{array}{c}84 / 97(86.6 \%) \\
173 / 204(84.8 \%)\end{array}$ & $\begin{array}{c}13 / 97(13.4 \%) \\
31 / 204(15.2 \%)\end{array}$ & 0.73 & \\
\hline $\begin{array}{r}\text { Preoperative iEEG } \\
\text { Yes } \\
\text { No }\end{array}$ & $\begin{array}{c}37 / 43(86.0 \%) \\
292 / 346(84.4 \%)\end{array}$ & $\begin{array}{c}6 / 43(14.0 \%) \\
54 / 346(15.6 \%)\end{array}$ & $>0.99$ & \\
\hline $\begin{array}{c}\text { Preoperative psychiatric disease } \\
\text { Yes } \\
\text { No }\end{array}$ & $\begin{array}{c}78 / 94(83.0 \%) \\
194 / 227(85.5 \%)\end{array}$ & $\begin{array}{c}16 / 94(17.0 \%) \\
33 / 227(14.5 \%)\end{array}$ & 0.61 & \\
\hline $\begin{array}{c}\text { Preoperative cognitive disorders } \\
\text { No } \\
\text { Yes }\end{array}$ & $\begin{array}{l}27 / 29(93.1 \%) \\
250 / 299(83.6 \%)\end{array}$ & $\begin{array}{c}2 / 29(6.9 \%) \\
49 / 299(16.4 \%)\end{array}$ & 0.28 & \\
\hline $\begin{array}{c}\text { Side of surgery } \\
\begin{array}{c}\text { Right } \\
\text { Left }\end{array}\end{array}$ & $\begin{array}{l}157 / 183(85.8 \%) \\
172 / 206(83.5 \%)\end{array}$ & $\begin{array}{l}26 / 183(14.2 \%) \\
34 / 206(16.5 \%)\end{array}$ & 0.57 & \\
\hline $\begin{array}{c}\text { Surgical approach } \\
\text { Transylvian SAH } \\
\text { Transcortical SAH } \\
\text { ATL }\end{array}$ & $\begin{array}{c}30 / 36(83.3 \%) \\
126 / 144(87.5 \%) \\
173 / 209(82.8 \%)\end{array}$ & $\begin{array}{c}6 / 36(16.7 \%) \\
18 / 144(12.5 \%) \\
36 / 209(17.2 \%)\end{array}$ & 0.47 & \\
\hline $\begin{array}{r}\text { Histology of HS } \\
\text { HS ILAE type } 1 \\
\text { HS ILAE type } 2 \\
\text { HS ILAE type } 3 \\
\text { No-HS }\end{array}$ & $\begin{array}{c}161 / 189(85.2 \%) \\
41 / 47(87.2 \%) \\
3 / 3(100.0 \%) \\
10 / 12(83.3 \%)\end{array}$ & $\begin{array}{c}28 / 189(14.8 \%) \\
6 / 47(12.8 \%) \\
0 / 3(0.0 \%) \\
2 / 12(16.7 \%)\end{array}$ & 0.88 & \\
\hline
\end{tabular}

Table 2. Predictors of overall complications.

Characteristics significant in univariate analysis are shown in bold. All variables significant in univariate analysis $(P<0.20)$ were used in multivariate analysis.

* Significant multivariate $P$-value $(P<0.05)$. 


\begin{tabular}{|c|c|c|c|c|}
\hline $\begin{array}{l}\text { Variables } \\
\text { n/N }(\%) \text { or mean } \pm \mathrm{SD}\end{array}$ & $\begin{array}{c}\text { No major } \\
\text { complication }\end{array}$ & $\begin{array}{c}\text { Major } \\
\text { complication }\end{array}$ & $\begin{array}{c}\text { Univariate } \\
P \text {-value }\end{array}$ & $\begin{array}{c}\text { Multivariate } \\
P \text {-value }\end{array}$ \\
\hline Age at surgery, $y$, mean \pm SD & $36.9 \pm 10.5$ & $36.8 \pm 10.5$ & 0.98 & \\
\hline Duration of epilepsy, $y$, mean \pm SD & $24.8 \pm 11.5$ & $27.0 \pm 8.6$ & 0.45 & \\
\hline Seizure frequency / $\mathrm{m}$, mean $\pm \mathrm{SD}$ & $10.9 \pm 13.9$ & $5.3 \pm 3.2$ & 0.12 & 0.12 \\
\hline $\begin{array}{l}\text { Male } \\
\text { Female }\end{array}$ & $\begin{array}{l}175 / 184(95.1 \%) \\
198 / 205(96.6 \%)\end{array}$ & $\begin{array}{l}9 / 184(4.9 \%) \\
7 / 205(3.4 \%)\end{array}$ & 0.61 & \\
\hline $\begin{array}{c}\text { Dominant hand } \\
\text { Right } \\
\text { Left } \\
\text { Ambidextrous }\end{array}$ & $\begin{array}{c}317 / 331(95.8 \%) \\
45 / 46(97.8 \%) \\
8 / 9(88.9 \%)\end{array}$ & $\begin{array}{c}14 / 331(4.2 \%) \\
1 / 46(2.2 \%) \\
1 / 9(11.1 \%)\end{array}$ & 0.46 & \\
\hline $\begin{array}{c}\text { Associated disease } \\
\text { Yes } \\
\text { No }\end{array}$ & $\begin{array}{c}33 / 35(94.3 \%) \\
328 / 342(95.9 \%)\end{array}$ & $\begin{array}{c}2 / 35(5.7 \%) \\
14 / 342(4.1 \%)\end{array}$ & 0.65 & \\
\hline $\begin{array}{r}\text { Preoperative MRI } \\
\text { HS pattern } \\
\text { Normal }\end{array}$ & $\begin{array}{c}293 / 306(95.8 \%) \\
15 / 16(93.8 \%)\end{array}$ & $\begin{array}{c}13 / 306(4.2 \%) \\
1 / 16(6.2 \%)\end{array}$ & 0.52 & \\
\hline $\begin{array}{c}\text { EEG: bitemporal abnormalities } \\
\text { Yes } \\
\text { No }\end{array}$ & $\begin{array}{c}83 / 84(98.8 \%) \\
205 / 217(94.5 \%)\end{array}$ & $\begin{array}{c}1 / 84(1.2 \%) \\
12 / 217(5.5 \%)\end{array}$ & 0.12 & 0.99 \\
\hline $\begin{array}{c}\text { Extratemporal ictal abnormalities } \\
\text { Yes } \\
\text { No }\end{array}$ & $\begin{array}{c}94 / 97(96.9 \%) \\
194 / 204(95.1 \%)\end{array}$ & $\begin{array}{c}3 / 97(3.1 \%) \\
10 / 204(4.9 \%)\end{array}$ & 0.56 & \\
\hline $\begin{array}{r}\text { Preoperative iEEG } \\
\text { Yes } \\
\text { No }\end{array}$ & $\begin{array}{c}41 / 43(95.3 \%) \\
332 / 346(96.0 \%)\end{array}$ & $\begin{array}{c}2 / 43(4.7 \%) \\
14 / 346(4.0 \%)\end{array}$ & 0.69 & \\
\hline $\begin{array}{c}\text { Preoperative psychiatric disease } \\
\text { Yes } \\
\text { No }\end{array}$ & $\begin{array}{c}90 / 94(95.7 \%) \\
218 / 227(96.0 \%)\end{array}$ & $\begin{array}{l}4 / 94(4.3 \%) \\
9 / 227(4.0 \%)\end{array}$ & $>0.99$ & \\
\hline $\begin{array}{c}\text { Preoperative cognitive disorders } \\
\text { No } \\
\text { Yes }\end{array}$ & $\begin{array}{l}29 / 29(100.0 \%) \\
285 / 299(95.3 \%)\end{array}$ & $\begin{array}{c}0 / 29(0.0 \%) \\
14 / 299(4.7 \%)\end{array}$ & 0.62 & \\
\hline $\begin{array}{r}\text { Side of surgery } \\
\text { Right } \\
\text { Left }\end{array}$ & $\begin{array}{l}175 / 183(95.6 \%) \\
198 / 206(96.1 \%)\end{array}$ & $\begin{array}{l}8 / 183(4.4 \%) \\
8 / 206(3.9 \%)\end{array}$ & $>0.99$ & \\
\hline $\begin{array}{c}\text { Surgical approach } \\
\text { Transylvian SAH } \\
\text { Transcortical SAH } \\
\text { ATL }\end{array}$ & $\begin{array}{c}35 / 36(97.2 \%) \\
141 / 144(97.9 \%) \\
197 / 209(94.3 \%)\end{array}$ & $\begin{array}{c}1 / 36(2.8 \%) \\
3 / 144(2.1 \%) \\
12 / 209(5.7 \%)\end{array}$ & 0.30 & \\
\hline $\begin{array}{c}\text { Surgical approach } \\
\text { Transcortical SAH } \\
\text { ATL }\end{array}$ & $\begin{array}{l}141 / 144(97.9 \%) \\
197 / 209(94.3 \%)\end{array}$ & $\begin{array}{c}3 / 144(2.1 \%) \\
12 / 209(5.7 \%)\end{array}$ & 0.11 & $0.03 *$ \\
\hline $\begin{array}{r}\text { Histology of HS } \\
\text { HS ILAE type } 1 \\
\text { HS ILAE type } 2 \\
\text { HS ILAE type } 3 \\
\text { No-HS }\end{array}$ & $\begin{array}{c}179 / 189(94.7 \%) \\
47 / 47(100.0 \%) \\
3 / 3(100.0 \%) \\
11 / 12(91.7 \%)\end{array}$ & $\begin{array}{c}10 / 189(5.3 \%) \\
0 / 47(0.0 \%) \\
0 / 3(0.0 \%) \\
1 / 12(8.3 \%)\end{array}$ & 0.37 & \\
\hline
\end{tabular}

Table 3. Predictors of major complications.

Characteristics significant in univariate analysis are shown in bold. All variables significant in univariate analysis $(P<0.20)$ were used in multivariate analysis.

* Significant multivariate $P$-value $(P<0.05)$. 


\begin{tabular}{|c|c|c|c|c|}
\hline $\begin{array}{l}\text { Variables } \\
\text { n/N }(\%) \text { or mean } \pm \text { SD }\end{array}$ & $\begin{array}{l}\text { No neurological } \\
\text { complication }\end{array}$ & $\begin{array}{l}\text { Neurological } \\
\text { complication }\end{array}$ & $\begin{array}{c}\text { Univariate } \\
P \text {-value }\end{array}$ & $\begin{array}{c}\text { Multivariate } \\
P \text {-value }\end{array}$ \\
\hline Age at surgery, $y$, mean \pm SD & $36.9 \pm 10.5$ & $35.8 \pm 10.2$ & 0.70 & \\
\hline Duration of epilepsy, $y$, mean \pm SD & $25.0 \pm 11.5$ & $23.8 \pm 7.7$ & 0.71 & \\
\hline Seizure frequency / $\mathrm{m}$, mean $\pm \mathrm{SD}$ & $10.6 \pm 13.7$ & $12.1 \pm 14.4$ & 0.69 & \\
\hline \multicolumn{5}{|l|}{ Gender } \\
\hline $\begin{array}{c}\text { Male } \\
\text { Female }\end{array}$ & $177 / 184(96.2 \%)$ & $7 / 184(3.8 \%)$ & $>0.99$ & \\
\hline $\begin{array}{l}\text { Female } \\
\text { Dominant hand }\end{array}$ & $197 / 205(96.1 \%)$ & $8 / 205(3.9 \%)$ & & \\
\hline \multicolumn{5}{|l|}{ Dominant hand } \\
\hline Right & $321 / 331(97.0 \%)$ & $10 / 331(3.0 \%)$ & & \\
\hline Left & $43 / 46(93.5 \%)$ & $3 / 46(6.5 \%)$ & 0.008 & 0.13 \\
\hline Ambidextrous & $7 / 9(77.8 \%)$ & $2 / 9(22.2 \%)$ & & \\
\hline \multicolumn{5}{|l|}{ Associated disease } \\
\hline Yes & $34 / 35(97.1 \%)$ & $1 / 35(2.9 \%)$ & $>0.99$ & \\
\hline No & $329 / 342(96.2 \%)$ & $13 / 342(3.8 \%)$ & $y$ & \\
\hline \multicolumn{5}{|l|}{ Preoperative MRI } \\
\hline HS pattern & $297 / 306(97.1 \%)$ & $9 / 306(2.9 \%)$ & 0.40 & \\
\hline Normal & $15 / 16(93.8 \%)$ & $1 / 16(6.2 \%)$ & & \\
\hline \multicolumn{5}{|l|}{ Extratemporal ictal abnormalities } \\
\hline Yes & $82 / 84(97.6 \%)$ & $2 / 84(2.4 \%)$ & $>0.99$ & \\
\hline No & $210 / 217(96.8 \%)$ & $7 / 217(3.2 \%)$ & & \\
\hline \multicolumn{5}{|l|}{ Atypical ictal EEG } \\
\hline Yes & 94/97 (96.9\%) & $3 / 97(3.1 \%)$ & $>0.99$ & \\
\hline No & $198 / 204(97.1 \%)$ & $6 / 204(2.9 \%)$ & & \\
\hline \multicolumn{5}{|l|}{ Preoperative iEEG } \\
\hline Yes & $40 / 43(93.0 \%)$ & $3 / 43(7.0 \%)$ & 0.22 & \\
\hline No & $334 / 346(96.5 \%)$ & $12 / 346(3.5 \%)$ & & \\
\hline \multicolumn{5}{|l|}{ Preoperative psychiatric disease } \\
\hline Yes & 92/94 (97.9\%) & $2 / 94(2.1 \%)$ & 0.73 & \\
\hline No & $219 / 227(96.5 \%)$ & $8 / 227(3.5 \%)$ & & \\
\hline \multicolumn{5}{|l|}{ Preoperative cognitive disorders } \\
\hline No & $28 / 29(96.6 \%)$ & $1 / 29(3.4 \%)$ & $>0.99$ & \\
\hline Yes & $288 / 299(96.3 \%)$ & $11 / 299(3.7 \%)$ & & \\
\hline \multicolumn{5}{|l|}{ Side of surgery } \\
\hline Right & $178 / 183(97.3 \%)$ & $5 / 183(2.7 \%)$ & 0.30 & \\
\hline Left & $196 / 206(95.1 \%)$ & $10 / 206(4.9 \%)$ & & \\
\hline \multicolumn{5}{|l|}{ Surgical approach } \\
\hline Transylvian SAH & $34 / 36(94.4 \%)$ & $2 / 36(5.6 \%)$ & & \\
\hline Transcortical SAH & $142 / 144(98.6 \%)$ & 2/144 (1.4\%) & 0.15 & NA \\
\hline ATL & $198 / 209(94.7 \%)$ & $11 / 209(5.3 \%)$ & & \\
\hline \multicolumn{5}{|l|}{ Surgical approach } \\
\hline Transcortical SAH & $142 / 144(98.6 \%)$ & $2 / 144(1.4 \%)$ & 0.08 & 0.08 \\
\hline ATL & $198 / 209(94.7 \%)$ & $11 / 209(5.3 \%)$ & & \\
\hline \multicolumn{5}{|l|}{ Histology of HS } \\
\hline HS ILAE type 1 & $181 / 189(95.8 \%)$ & $8 / 189(4.2 \%)$ & & \\
\hline HS ILAE type 2 & 47/47 (100.0\%) & $0 / 47(0.0 \%)$ & 0.41 & \\
\hline HS ILAE type 3 & $3 / 3(100.0 \%)$ & $0 / 3(0.0 \%)$ & & \\
\hline No-HS & $11 / 12(91.7 \%)$ & $1 / 12(8.3 \%)$ & & \\
\hline
\end{tabular}

Table 4. Predictors of neurological complications.

Characteristics significant in univariate analysis are shown in bold. All variables significant in univariate analysis $(P<0.20)$ were used in multivariate analysis.

NA, not available. 


\begin{tabular}{|c|c|c|c|c|}
\hline $\begin{array}{l}\text { Variables } \\
\text { n/N }(\%) \text { or mean } \pm \mathrm{SD}\end{array}$ & $\begin{array}{c}\text { No symptomatic } \\
\text { visual field defect }\end{array}$ & $\begin{array}{c}\text { Symptomatic } \\
\text { visual field defect }\end{array}$ & $\begin{array}{c}\text { Univariate } \\
P \text {-value }\end{array}$ & $\begin{array}{c}\text { Multivariate } \\
P \text {-value }\end{array}$ \\
\hline Age at surgery, y, mean \pm SD & $36.9 \pm 10.6$ & $36.7 \pm 10.1$ & 0.90 & \\
\hline Duration of epilepsy, $y$, mean \pm SD & $24.7 \pm 11.4$ & $26.7 \pm 11.3$ & 0.32 & \\
\hline Seizure frequency / $\mathrm{m}$, mean \pm SD & $10.9 \pm 14.2$ & $7.7 \pm 6.4$ & 0.19 & \\
\hline $\begin{array}{c}\text { Gender } \\
\text { Male } \\
\text { Female }\end{array}$ & $\begin{array}{l}162 / 184(88.0 \%) \\
190 / 205(92.7 \%)\end{array}$ & $\begin{array}{c}22 / 184(12.0 \%) \\
15 / 205(7.3 \%)\end{array}$ & 0.12 & $0.04 *$ \\
\hline $\begin{array}{c}\text { Dominant hand } \\
\text { Right } \\
\text { Left } \\
\text { Ambidextrous }\end{array}$ & $\begin{array}{c}300 / 331(90.6 \%) \\
41 / 46(89.1 \%) \\
8 / 9(88.9 \%)\end{array}$ & $\begin{array}{c}31 / 331(9.4 \%) \\
5 / 46(10.9 \%) \\
1 / 9(11.1 \%)\end{array}$ & 0.94 & \\
\hline $\begin{array}{c}\text { Associated disease } \\
\text { Yes } \\
\text { No }\end{array}$ & $\begin{array}{c}34 / 35(97.1 \%) \\
307 / 342(89.8 \%)\end{array}$ & $\begin{array}{c}1 / 35(2.9 \%) \\
35 / 342(10.2 \%)\end{array}$ & 0.23 & \\
\hline $\begin{array}{r}\text { Preoperative MRI } \\
\text { HS pattern } \\
\text { Normal }\end{array}$ & $\begin{array}{c}279 / 306(91.2 \%) \\
15 / 16(93.8 \%)\end{array}$ & $\begin{array}{c}27 / 306(8.8 \%) \\
1 / 16(6.2 \%)\end{array}$ & $>0.99$ & \\
\hline $\begin{array}{c}\text { EEG: bitemporal abnormalities } \\
\text { Yes } \\
\text { No }\end{array}$ & $\begin{array}{c}79 / 84(94.0 \%) \\
197 / 217(90.8 \%)\end{array}$ & $\begin{array}{c}5 / 84(6.0 \%) \\
20 / 217(9.2 \%)\end{array}$ & 0.49 & \\
\hline $\begin{array}{c}\text { Extratemporal ictal abnormalities } \\
\text { Yes } \\
\text { No }\end{array}$ & $\begin{array}{c}88 / 97(90.7 \%) \\
188 / 204(92.2 \%)\end{array}$ & $\begin{array}{c}9 / 97(9.3 \%) \\
16 / 204(7.8 \%)\end{array}$ & 0.66 & \\
\hline $\begin{array}{r}\text { Preoperative iEEG } \\
\text { Yes } \\
\text { No }\end{array}$ & $\begin{array}{c}40 / 43(93.0 \%) \\
312 / 346(90.2 \%)\end{array}$ & $\begin{array}{c}3 / 43(7.0 \%) \\
34 / 346(9.8 \%)\end{array}$ & 0.78 & \\
\hline $\begin{array}{c}\text { Preoperative psychiatric disease } \\
\text { Yes } \\
\text { No }\end{array}$ & $\begin{array}{c}82 / 94(87.2 \%) \\
208 / 227(91.6 \%)\end{array}$ & $\begin{array}{l}12 / 94(12.8 \%) \\
19 / 227(8.4 \%)\end{array}$ & 0.22 & \\
\hline $\begin{array}{c}\text { Preoperative cognitive disorders } \\
\text { No } \\
\text { Yes }\end{array}$ & $\begin{array}{c}28 / 29(96.6 \%) \\
267 / 299(89.3 \%)\end{array}$ & $\begin{array}{c}1 / 29(3.4 \%) \\
32 / 299(10.7 \%)\end{array}$ & 0.33 & \\
\hline $\begin{array}{r}\text { Side of surgery } \\
\text { Right } \\
\text { Left }\end{array}$ & $\begin{array}{l}166 / 183(90.7 \%) \\
186 / 206(90.3 \%)\end{array}$ & $\begin{array}{l}17 / 183(9.3 \%) \\
20 / 206(9.7 \%)\end{array}$ & $>0.99$ & \\
\hline $\begin{array}{c}\text { Surgical approach } \\
\text { Transylvian SAH } \\
\text { Transcortical SAH } \\
\text { ATL }\end{array}$ & $\begin{array}{l}32 / 36(88.9 \%) \\
132 / 144(91.7 \%) \\
188 / 209(90.0 \%)\end{array}$ & $\begin{array}{c}4 / 36(11.1 \%) \\
12 / 144(8.3 \%) \\
21 / 209(10.0 \%)\end{array}$ & 0.81 & \\
\hline $\begin{array}{l}\text { Histology of HS } \\
\text { HS ILAE type } 1 \\
\text { HS ILAE type } 2 \\
\text { HS ILAE type } 3 \\
\text { No-HS }\end{array}$ & $\begin{array}{c}172 / 189(91.0 \%) \\
42 / 47(89.4 \%) \\
3 / 3(100.0 \%) \\
11 / 12(91.7 \%)\end{array}$ & $\begin{array}{c}17 / 189(9.0 \%) \\
5 / 47(10.6 \%) \\
0 / 3(0.0 \%) \\
1 / 12(8.3 \%)\end{array}$ & 0.93 & \\
\hline
\end{tabular}

Table 5. Predictors of symptomatic visual field defects.

Characteristics significant in univariate analysis are shown in bold.

* Significant multivariate $P$-value $(P<0.05)$. 


\begin{tabular}{|c|c|c|c|c|c|}
\hline $\begin{array}{c}\text { Reference } \\
\text { (period) }\end{array}$ & ${ }^{\text {Institution }}{ }_{\mathrm{ACCE}}$ & $\begin{array}{c}\text { Surgical } \\
\text { approach }\end{array}$ & $\mathrm{JSCR}^{\mathbf{n}} \mathrm{PTT}$ & $\begin{array}{c}\text { Complications } \\
\text { overall/major/permanent } \\
\end{array}$ & Death \\
\hline $\begin{array}{l}\text { Rydenhag }^{10} \\
(1990-1995)\end{array}$ & $\begin{array}{l}\text { Swedish National Epilepsy } \\
\text { Surgery Register, Sweden }\end{array}$ & ATL & 168 & $12.4 \% / 2.9 \% / ?$ & $0 \%$ \\
\hline $\begin{array}{c}\text { Behrens }^{11} \\
(1987-1997)\end{array}$ & $\begin{array}{l}\text { University of Bonn } \\
\text { Bonn, Germany }\end{array}$ & ts $\mathrm{SAH}$ & 279 & $? / 4.7 \% / 2.3 \%$ & $0 \%$ \\
\hline $\begin{array}{l}\text { Salanova }^{12} \\
(1984-1999)\end{array}$ & $\begin{array}{c}\text { Indiana University } \\
\text { Indianapolis, Indiana, USA }\end{array}$ & $?$ & 104 & $9.5 \% / 5.8 \% / 1.3 \%$ & $0 \%$ \\
\hline $\begin{array}{c}\text { Sindou }^{13} \\
(1994-2003)\end{array}$ & $\begin{array}{l}\text { Pierre Wertheimer Hospital } \\
\text { Lyon, France }\end{array}$ & ATL, ts SAH & 100 & $19.0 \% / 7.0 \% / 2.0 \%$ & $0 \%$ \\
\hline $\begin{array}{c}\text { Bate }^{14} \\
(1996-2004)\end{array}$ & $\begin{array}{l}\text { Walton Centre } \\
\text { Liverpool, GB }\end{array}$ & SAH, ATL & 114 & $10.5 \% / 6.1 \% / 2.6 \%$ & $0 \%$ \\
\hline $\begin{array}{l}\text { Tanriverdi }^{15} \\
(1976-2006)\end{array}$ & $\begin{array}{c}\text { MNI } \\
\text { Montreal, Canada }\end{array}$ & $?$ & 1232 & $5.5 \% / 2.8 \% / ?$ & $0 \%$ \\
\hline $\begin{array}{c}\text { Bandt }^{16} \\
(1997-2007)\end{array}$ & $\begin{array}{l}\text { Washington University } \\
\text { St Louis, MO, USA }\end{array}$ & tcT2 SAH & 76 & $? / 3.0 \% / 0.0 \%$ & $0 \%$ \\
\hline $\begin{array}{l}\text { Iachinski1 }^{17} \\
(1998-2010)\end{array}$ & $\begin{array}{l}\text { Curitiba institute } \\
\text { Curitiba, Brazil }\end{array}$ & ATL & 67 & $17.9 \% / 13.4 \% / 0.0 \%$ & $0 \%$ \\
\hline $\begin{array}{c}\text { Vale }^{3} \\
(1998-2012)\end{array}$ & $\begin{array}{l}\text { University of South Florida } \\
\text { Tampa, Florida, USA }\end{array}$ & tcT3 SAH & 483 & $? / 2.7 \% / 0.2 \%$ & $0 \%$ \\
\hline $\begin{array}{c}\text { Yang }^{18} \\
(2004-2012)\end{array}$ & $\begin{array}{c}\text { Fuzhou General Hospital } \\
\text { Fuzhou, China }\end{array}$ & $\mathrm{CAH}$ & 683 & $? / 1.8 \% / ?$ & $0 \%$ \\
\hline $\begin{array}{l}\text { Josephson }^{19} \\
(1997-2012)\end{array}$ & $\begin{array}{l}\text { Meta-analysis } \\
\text { (5 studies) }\end{array}$ & $\begin{array}{l}\text { SAH } \\
\text { ATL }\end{array}$ & $\begin{array}{l}309 \\
392\end{array}$ & $\begin{array}{l}? / ? / 0.0-3.1 \% \\
? / ? / 0.0-2.4 \%\end{array}$ & $?$ \\
\hline $\begin{array}{c}\text { Current } \\
\text { series } \\
(\mathbf{1 9 9 0 - 2 0 1 5 )}\end{array}$ & $\begin{array}{c}\text { La Pitié-Salpêtrière } \\
\text { University Hospital } \\
\text { Paris, France }\end{array}$ & $\begin{array}{l}\text { Total } \\
\text { tcT1 SAH } \\
\text { ts SAH } \\
\text { ATL } \\
\end{array}$ & $\begin{array}{c}389 \\
144 \\
36 \\
209 \\
\end{array}$ & $\begin{array}{c}\mathbf{1 5 . 4 \% / 4 . 1 \% / 0 . 5 \%} \\
12.5 \% / 2.1 \% / 0.0 \% \\
16.7 \% / 2.8 \% / 0.0 \% \\
17.2 \% / 5.7 \% / 1.0 \% \\
\end{array}$ & $\mathbf{0 \%}$ \\
\hline
\end{tabular}

Table 6. Morbidity and mortality of MTLE surgery: Literature review.

CAH, cortico-amygdalohippocampectomy; ts, transylvian; tc, transcortical; T1, superior temporal gyrus; T2, middle temporal gyrus; T3, inferior temporal gyrus. 


\begin{tabular}{|c|c|c|c|c|}
\hline $\begin{array}{c}\text { References } \\
\text { (period or publication) }\end{array}$ & Institution & $\begin{array}{l}\text { Surgical } \\
\text { approach }\end{array}$ & $\mathbf{n}$ & $\begin{array}{l}\text { Symptomatic and } \\
\text { asymptomatic } \\
\text { visual field defects }\end{array}$ \\
\hline $\begin{array}{l}\operatorname{Egan}^{25} \\
(2000)\end{array}$ & $\begin{array}{l}\text { Casey Eye Institute, } \\
\text { Portland, ME, USA }\end{array}$ & $\begin{array}{c}\text { ATL } \\
\text { tcT2 SAH }\end{array}$ & $\begin{array}{l}15 \\
14\end{array}$ & $\begin{array}{l}73 \% \\
79 \%\end{array}$ \\
\hline $\begin{array}{l}\text { Hervas-Navidad }^{26} \\
\quad(1995-1998)\end{array}$ & $\begin{array}{c}\text { Virgen de las Nieves Hospital, } \\
\text { Grenada, Spain }\end{array}$ & ATL & 30 & $90 \%$ \\
\hline $\begin{array}{l}\text { Pathak-Ray }^{27} \\
\qquad(2002)\end{array}$ & $\begin{array}{l}\text { University Hospital of Wales, } \\
\text { Cardiff, GB }\end{array}$ & ATL & 14 & $64 \%$ \\
\hline $\begin{array}{l}\text { Nilsson } \\
(1987-1999)\end{array}$ & $\begin{array}{c}\text { Sahlgrenska University Hospital, } \\
\text { Goteborg, Sweden }\end{array}$ & ATL & 50 & $50 \%$ \\
\hline $\begin{array}{c}\text { Barton }^{29} \\
(2005)\end{array}$ & $\begin{array}{c}\text { Beth Israel Deaconess Medical Center, } \\
\text { Boston, MA, USA }\end{array}$ & ATL & 29 & $100 \%$ \\
\hline $\begin{array}{l}\text { Yeni }^{30} \\
(2008)\end{array}$ & $\begin{array}{l}\text { Istanbul University, } \\
\text { Istanbul, Turkey }\end{array}$ & ts SAH & 30 & $37 \%$ \\
\hline $\begin{array}{l}\text { Mengesha }^{31} \\
(1990-2006)\end{array}$ & $\begin{array}{c}\text { Vanderbilt University Medical Center, } \\
\text { Nashville, TN, USA }\end{array}$ & $\begin{array}{l}\text { tcT2 SAH } \\
\text { ATL }\end{array}$ & $\begin{array}{l}18 \\
33\end{array}$ & $\begin{array}{l}89 \% \\
91 \%\end{array}$ \\
\hline $\begin{array}{l}\text { Jeelani }^{32} \\
(1984-2004)\end{array}$ & $\begin{array}{c}\text { Great Ormond Street Hospital, } \\
\text { London, GB }\end{array}$ & ATL & 105 & $15 \%$ \\
\hline $\begin{array}{c}\text { Yam }^{33} \\
(1991-2007)\end{array}$ & $\begin{array}{l}\text { London Health Sciences Centre, } \\
\text { London, Ontario, Canada }\end{array}$ & ATL & 75 & $65 \%$ \\
\hline $\begin{array}{l}\text { Current series } \\
(\mathbf{1 9 9 0 - 2 0 1 5 )}\end{array}$ & $\begin{array}{l}\text { La Pitié-Salpêtrière } \\
\text { University Hospital } \\
\text { Paris, France }\end{array}$ & $\begin{array}{c}\text { Total } \\
\text { tcT1 SAH } \\
\text { ts SAH } \\
\text { ATL }\end{array}$ & $\begin{array}{c}323 \\
140 \\
13 \\
170\end{array}$ & $\begin{array}{l}39 \% \\
34 \% \\
46 \% \\
43 \% \\
\end{array}$ \\
\hline
\end{tabular}

Table 7. Visual field defects related to MTLE surgery: Literature review.

ts, transylvian; tc, transcortical; T1, superior temporal gyrus; T2, middle temporal gyrus. 


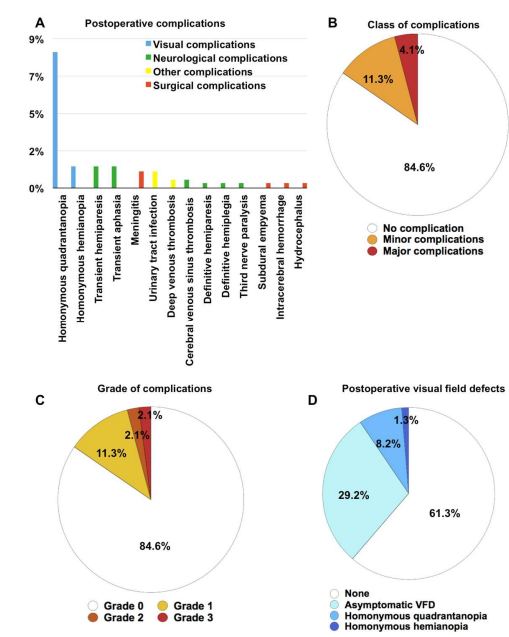




\section{HIGHLIGHTS}

- The overall rate of complications was $15.4 \%$.

- Persistent neurological deficits occurred in $0.5 \%$ of the patients.

- VFDs occurred in $38.7 \%$ of the patients, but only $9.5 \%$ were symptomatic.

- ATL was associated with major complications more often than transcortical SAH.

- Transcortical SAH is the preferred approach to minimize complications of HS surgery. 


\begin{tabular}{|c|c|c|c|c|}
\hline $\begin{array}{l}\text { Variables } \\
\text { n/N }(\%) \text { or mean } \pm \mathrm{SD}\end{array}$ & $\begin{array}{c}\text { No surgical } \\
\text { complication }\end{array}$ & $\begin{array}{c}\text { Surgical } \\
\text { complication }\end{array}$ & $\begin{array}{c}\text { Univariate } \\
P \text {-value }\end{array}$ & $\begin{array}{c}\text { Multivariate } \\
P \text {-value }\end{array}$ \\
\hline Age at surgery, $y$, mean \pm SD & $36.8 \pm 10.5$ & $40.9 \pm 12.1$ & 0.30 & \\
\hline Duration of epilepsy, $y$, mean \pm SD & $24.9 \pm 11.4$ & $28.1 \pm 10.2$ & 0.46 & \\
\hline Seizure frequency / $\mathrm{m}$, mean $\pm \mathrm{SD}$ & $10.8 \pm 13.8$ & $4.0 \pm 1.9$ & 0.19 & NA \\
\hline $\begin{array}{c}\text { Male } \\
\text { Female }\end{array}$ & $\begin{array}{l}180 / 184(97.8 \%) \\
202 / 205(98.5 \%)\end{array}$ & $\begin{array}{l}4 / 184(2.2 \%) \\
3 / 205(1.5 \%)\end{array}$ & 0.71 & \\
\hline $\begin{array}{c}\text { Dominant hand } \\
\text { Right } \\
\text { Left } \\
\text { Ambidextrous }\end{array}$ & $\begin{array}{c}324 / 331(97.9 \%) \\
46 / 46(100.0 \%) \\
9 / 9(88.9 \%)\end{array}$ & $\begin{array}{c}7 / 331(2.1 \%) \\
0 / 46(0.0 \%) \\
0 / 9(0.0 \%)\end{array}$ & 0.55 & \\
\hline $\begin{array}{r}\text { Associated disease } \\
\text { Yes } \\
\text { No }\end{array}$ & $\begin{array}{c}34 / 35(97.1 \%) \\
336 / 342(98.2 \%)\end{array}$ & $\begin{array}{l}1 / 35(2.9 \%) \\
6 / 342(1.8 \%)\end{array}$ & 0.50 & \\
\hline $\begin{array}{r}\text { Preoperative MRI } \\
\text { HS pattern } \\
\text { Normal }\end{array}$ & $\begin{array}{c}299 / 306(97.7 \%) \\
16 / 16(93.8 \%)\end{array}$ & $\begin{array}{l}7 / 306(2.3 \%) \\
0 / 16(6.2 \%)\end{array}$ & $>0.99$ & \\
\hline $\begin{array}{c}\text { EEG: bitemporal abnormalities } \\
\text { Yes } \\
\text { No }\end{array}$ & $\begin{array}{c}83 / 84(98.8 \%) \\
211 / 217(97.2 \%)\end{array}$ & $\begin{array}{l}1 / 84(1.2 \%) \\
6 / 217(2.8 \%)\end{array}$ & 0.68 & \\
\hline $\begin{array}{c}\text { Extratemporal ictal abnormalities } \\
\text { Yes } \\
\text { No }\end{array}$ & $\begin{array}{c}96 / 97(99.0 \%) \\
198 / 204(97.1 \%)\end{array}$ & $\begin{array}{c}1 / 97(1.0 \%) \\
6 / 204(2.9 \%)\end{array}$ & 0.43 & \\
\hline $\begin{array}{r}\text { Preoperative iEEG } \\
\text { Yes } \\
\text { No }\end{array}$ & $\begin{array}{c}42 / 43(97.7 \%) \\
340 / 346(98.3 \%)\end{array}$ & $\begin{array}{l}1 / 43(2.3 \%) \\
6 / 346(1.7 \%)\end{array}$ & 0.56 & \\
\hline $\begin{array}{c}\text { Preoperative psychiatric disease } \\
\text { Yes } \\
\text { No }\end{array}$ & $\begin{array}{c}91 / 94(96.8 \%) \\
223 / 227(98.2 \%)\end{array}$ & $\begin{array}{c}2 / 94(3.2 \%) \\
4 / 227(1.8 \%)\end{array}$ & 0.42 & \\
\hline $\begin{array}{c}\text { Preoperative cognitive disorders } \\
\text { No } \\
\text { Yes }\end{array}$ & $\begin{array}{l}29 / 29(100.0 \%) \\
293 / 299(98.0 \%)\end{array}$ & $\begin{array}{l}0 / 29(0.0 \%) \\
6 / 299(2.0 \%)\end{array}$ & $>0.99$ & \\
\hline $\begin{array}{r}\text { Side of surgery } \\
\text { Right } \\
\text { Left }\end{array}$ & $\begin{array}{l}181 / 183(98.9 \%) \\
201 / 206(97.6 \%)\end{array}$ & $\begin{array}{l}2 / 183(1.1 \%) \\
5 / 204(2.4 \%)\end{array}$ & 0.45 & \\
\hline $\begin{array}{c}\text { Surgical approach } \\
\text { Transylvian SAH } \\
\text { Transcortical SAH } \\
\text { ATL }\end{array}$ & $\begin{array}{c}35 / 36(97.2 \%) \\
142 / 144(98.6 \%) \\
205 / 209(98.1 \%)\end{array}$ & $\begin{array}{l}1 / 36(2.8 \%) \\
2 / 144(1.4 \%) \\
4 / 209(1.9 \%)\end{array}$ & 0.84 & \\
\hline $\begin{array}{l}\text { Histology of HS } \\
\text { HS ILAE type } 1 \\
\text { HS ILAE type } 2 \\
\text { HS ILAE type } 3 \\
\text { No-HS }\end{array}$ & $\begin{array}{c}186 / 189(98.4 \%) \\
47 / 47(100.0 \%) \\
3 / 3(100.0 \%) \\
12 / 12(100.0 \%)\end{array}$ & $\begin{array}{c}3 / 189(1.6 \%) \\
0 / 47(0.0 \%) \\
0 / 3(0.0 \%) \\
0 / 12(0.0 \%) \\
\end{array}$ & 0.80 & \\
\hline
\end{tabular}

Supplementary Table 1. Predictors of surgical complications.

Characteristics significant in univariate analysis are shown in bold. Because only 1 variable was found to be statistically significant after univariate analysis $(P<0.20)$, we did not perform multivariate analysis.

NA, not available. 


\section{$\underline{\text { Abbreviations }}$}

ATL, anterior temporal lobectomy

CT, computerized tomography

DVT, deep venous thrombosis

EEG, electroencephalogram

HS, hippocampal sclerosis

ILAE, international league against epilepsy

MRI, magnetic resonance imaging

MTLE, mesial temporal lobe epilepsy

MTLE-HS, mesial temporal lobe epilepsy associated with hippocampal sclerosis

SAH, selective amygdalohippocampectomy

STG, superior temporal gyrus

UTI, urinary tract infection

VFD, visual field defect 
I, Dr Bertrand Mathon, certify that this manuscript is a unique submission and is not considering for publication, in part or in full, with any other source in any medium. This manuscript has been written in accordance with the journal's instructions to authors. Each of the authors has read and concurs with the content of the final manuscript. All of the authors have made substantial contributions to the article and approved the version to be submitted. All authors certify that they have no affiliations with or involvement in any organization or entity with any financial interest (such as honoraria; educational grants; participation in speakers' bureaus; membership, employment, consultancies, stock ownership, or other equity interest; and expert testimony or patent-licensing arrangements), or non-financial interest (such as personal or professional relationships, affiliations, knowledge or beliefs) in the subject matter or materials discussed in this manuscript. 